\title{
FLT3 Gene Mutation Negative
}

National Cancer Institute

\section{Source}

National Cancer Institute. FLT3 Gene Mutation Negative. NCI Thesaurus. Code C148082.

A genetic finding indicating that FLT3 gene mutations have not been detected in a sample. 